\title{
Assessment of Natural Radioactivity Level and Radiological Index in the Vicinity of Lynas Rare-earth Processing Plants
}

\author{
W.M. ZAL U'YUN*, M.W. YII, K. MOHD ASHHAR, M.K. KHAIRUDDIN, \\ I. ABDUL KADIR AND Y. MOHD ABD WAHAB
}

\begin{abstract}
The findings of the study on assessment of natural radioactivity level and radiation hazard parameters in the vicinity of Lynas rare-earth processing plants are reported. This study aims to quantify the environmental levels of natural radionuclides in soil collected in the vicinity of Lynas rare-earth processing plants and thereby to assess potential radiological hazards to the environment. About 31 terrestrial sampling locations were chosen for collection of the soil samples. The activity concentrations of the naturally occurring radioactive material (NORM) members, i.e. ${ }^{226} \mathrm{Ra}$, ${ }^{228} \mathrm{Ra}$, ${ }^{238} \mathrm{U},{ }^{232} \mathrm{Th}$ and ${ }^{40} \mathrm{~K}$ were measured using HpGe gamma spectrometer after reaching 30 days of secular equilibrium with their daughters. The mean activity concentration of ${ }^{226} \mathrm{Ra}^{228} \mathrm{Ra}^{238} \mathrm{U},{ }^{232} \mathrm{Th}$ and ${ }^{40} \mathrm{~K}$ in soil samples were $35 \mathrm{~Bq} / \mathrm{kg}, 62 \mathrm{~Bq} / \mathrm{kg}, 38 \mathrm{~Bq} / \mathrm{kg}, 60 \mathrm{~Bq} / \mathrm{kg}$ and $245 \mathrm{~Bq} / \mathrm{kg}$, respectively. The estimated $\mathrm{Ra}_{\mathrm{eq}}$ and $\mathrm{H}_{\mathrm{ex}}$ readings due to natural environmental radiation in respectively lower than the recommended value of $370 \mathrm{~Bq} / \mathrm{kg}$ and unity. Meanwhile, the total air absorbed dosage rate was slightly higher than the estimated average global terrestrial radiation but much lower compared to other regions in Malaysia. The results indicated that the radiation hazard in the vicinity of the Lynas rare-earth processing plants was negligible. Thus, it could be concluded that there were no additional radiation level and no radiological hazard effects to the people living in the surrounding areas.
\end{abstract}

Key words: NORM; radioactivity; radiological; rare-earth processing

Assessment of natural ambient radioactivity and its radiological effects in the environment play an important role to protect the health hazard on the environment and general public due to the radiation (Kasoga et al. 2015). The contribution of ambient radioactivity to the background radiation in the environment is mainly from two prominent natural sources, i.e. high-energy cosmic ray particles from the atmosphere and radioactive nuclides that originated from the earth crust which is present everywhere in the environment, including the human body
(UNSCEAR 2000). The primary source of terrestrial radiation received by humans is of the naturally occurring radioactive material (NORM) associated and deposited with the formation of the earth's crust such as rocks, soils, ores, minerals, sediment, etc. The NORMs which are derived principally from ${ }^{40} \mathrm{~K}$ and the daughters of ${ }^{238} \mathrm{U}$ and ${ }^{232} \mathrm{Th}$ decay series such as radium, radon, actinium, protactinium, lead, and polonium. These progenies first appear in the lithosphere level, deposited on the surface soil before it has been washed and drained through 
several pathways such as weathering, erosion, fallout, rainwater and human activities into rivers transport and finally ended in the marine environment through estuary (Ahmad-Taufek 2004; Akram et al. 2004). In the terrestrial environment, these radioactive series are present in the soil and soil acts as a medium for transferring radionuclides in air and vegetables (Balakrishnan 2015).

These radioactive nuclides release radiation everywhere in our surroundings to which humans are exposed (Kasoga et al. 2015). In other words, although natural radioactivity is present at very low levels almost anywhere in the natural environment, everyone is exposed to it in air, food, and water. These amounts in the air are usually so small and do not constitute a health hazard (Yii et al. 2016). Also, the radiation exposure to the general public is due to unplanned and uncontrolled of human activities (e.g. industrial activities). Thus, uncontrolled activities involving NORM can contribute to ambient radioactivity in the environment, thus unwanted exposure and dispersal pose a risk to human health and the environment. Industrial activities such as oil and gas extraction, coal fired power generation, phosphate industries, zircon/zirconium industry, mining and processing of metals and rare-earth, etc. have been reported as potential sources of elevated naturally occurring radionuclides. The presence of NORM with elevated radionuclides concentrations could be an issue at any stage of an operation from the mineral feed stock, intermediate products, final products and the wastes generated during the process (IAEA 2005). In the past, the issue of NORM and their potential hazards associated with human health and contaminating the environment often raised concerns by the public but now many efforts on such environmental monitoring are implemented, and the problem can be solved and the potential radiological hazards can be reduced.

Study of the background or ambient radioactivity present in natural environmental samples such as vegetation, water, air, and soil provide vital information as they help to monitor the radioactivity levels found in the surroundings and also give an indication of changes in the radiation levels due to human activities (Hu et al. 2010). These studies also help to identify and evaluate the distribution of radionuclides in the area (IAEA 2010). Therefore, the present study is carried out with the primary objective to quantify the environmental levels of natural radionuclides in the soil collected at the vicinity of Lynas rare-earth processing plants and thereby to assess potential radiological hazards to the environment.

\section{EXPERIMENTAL DETAILS}

\section{Sampling Area}

Lynas rare-earth processing plants are situated in Gebeng Industrial Estate, adjacent to the Balok River. The estate lies within the capital city Kuantan in the Pahang state. The study areas were established within $3 \mathrm{~km}$ radius surrounding the plant and located within at a Latitude $3.97^{\circ}$ to $4.03^{\circ}$ North and Longitude $103.34^{\circ}$ to $103.42^{\circ}$ East (Figure 1).

\section{Soil Sample Collection}

About 31 soil samples were collected at randomly selected sampling points surrounding the Lynas Plants (Figure 1) in May 2014 to September 2015 which involved seven trips of sampling activities. Approximately $1 \mathrm{~kg}$ of composite surface soil samples was taken using a coring tool at less than $5 \mathrm{~cm}$ depth with 


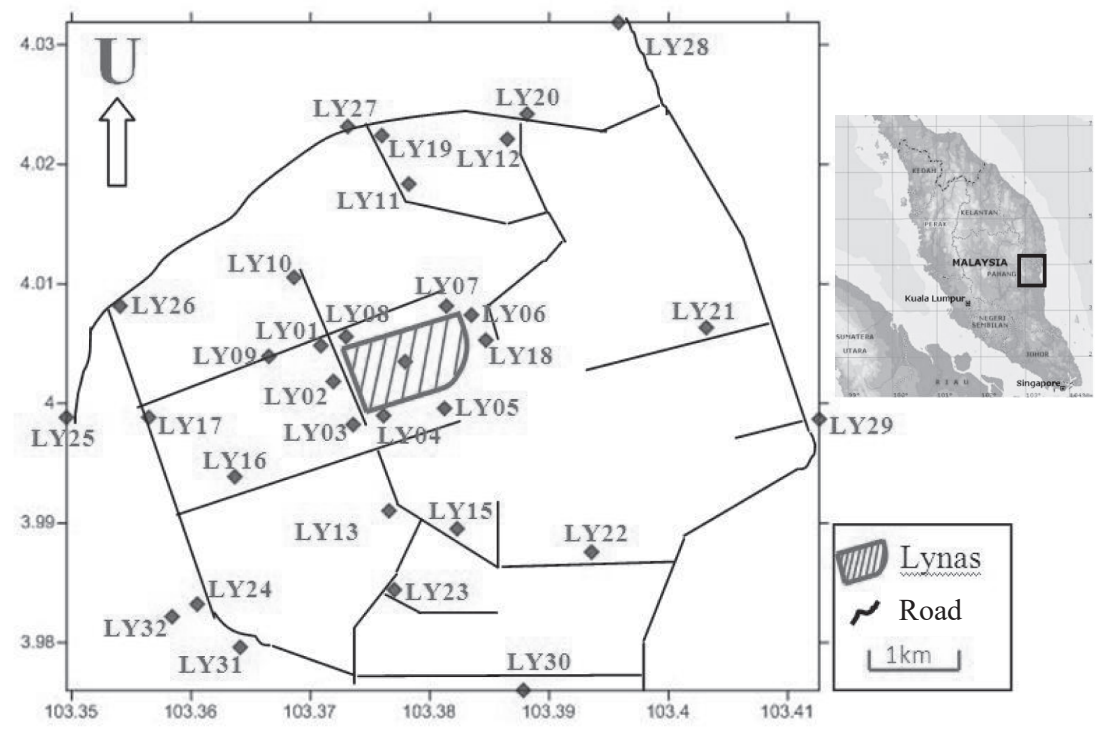

Figure 1. Location of the sampling points at the study area.

one-metre square area for each point. Stones, pebbles, vegetation, dried leaves, roots, etc. were cleared and removed from soil samples; then the collected samples were place into HDPE plastic bag, properly labelled and sealed before brought back to the laboratory for further analysis.

\section{Sample Preparation}

The collected soil samples were individually weighed, transferred into a steel tray and dried at $105^{\circ} \mathrm{C}$ in an electric scientific oven for a minimum of 24 hours until a constant weight was achieved. Then, the dried samples were ground to powder form and passed through a 200 mesh sieving machine. Samples were transferred into a $600 \mathrm{ml}$ Marinelli beaker, weighed and sealed with thick PVC tape to inhibit radon gases from escaping (Yii et al. 2016). All samples were then stored for a period in excessive of 30 days ( $>7$ half-live of ${ }^{222} \mathrm{Rn}$ and ${ }^{220} \mathrm{Rn}$ ) to establish secular equilibrium between parents and with their respective radioactive progeny before to gamma counting (Dowdall 2002; Yang et al. 2005).

\section{Gamma Counting}

Procedure for gamma counting was summarized from the technical report by Yii et al. (2016). All samples were individually counted using high purity germanium (HPGe) gamma spectrometry system with the p-type detector of $25 \%$ relative efficiency for 50000 seconds. It was calibrated using customized gamma multi-nuclides standard sources comprising of ${ }^{210} \mathrm{~Pb},{ }^{241} \mathrm{Am}$, ${ }^{109} \mathrm{Cd},{ }^{57} \mathrm{Co},{ }^{123 \mathrm{~m}} \mathrm{Te},{ }^{51} \mathrm{Cr},{ }^{113} \mathrm{Sn},{ }^{85} \mathrm{Sr},{ }^{137} \mathrm{Cs},{ }^{88} \mathrm{Y}$ and ${ }^{60} \mathrm{Co}$ in the same counting geometry. A container with the same geometry filled with inert materials counted during the weekend was used to determine the background counts. All measurements were corrected to the density and reference date.

The activities of ${ }^{226} \mathrm{Ra},{ }^{228} \mathrm{Ra},{ }^{232} \mathrm{Th}$, and ${ }^{238} \mathrm{U}$ were calculated through their progeny energy peaks i.e. ${ }^{214} \mathrm{~Pb}$ and ${ }^{214} \mathrm{Bi}$ for ${ }^{226} \mathrm{Ra}$, and 
${ }^{238} \mathrm{U} ;{ }^{228} \mathrm{Ac}$ for ${ }^{228} \mathrm{Ra}$; and ${ }^{212} \mathrm{~Pb},{ }^{228} \mathrm{Ac}$, and ${ }^{208} \mathrm{Tl}$ for ${ }^{232} \mathrm{Th}$. Meanwhile, ${ }^{40} \mathrm{~K}$ was calculated via directly its energy peak (Yang et al. 2005; El-Reefy et al. 2006). All activity calculations were corrected to the density and sampling date. The minimum detectable activities (MDA) for ${ }^{226} \mathrm{Ra},{ }^{228} \mathrm{Ra},{ }^{232} \mathrm{Th}$, and ${ }^{238} \mathrm{U}$ were $1 \mathrm{~Bq} / \mathrm{kg}$ after considering the sample size and counting time and ${ }^{40} \mathrm{~K}$ was $5 \mathrm{~Bq} / \mathrm{kg}$ (Yii et al. 2016).

\section{Calculation of Radiological Index}

The radiological index consists of several parameters. Among these are:

(i) Radium equivalent activity $\mathrm{Ra}_{\mathrm{eq}}$ concentration index.

Radium equivalent activity concentration index with a symbol of $\mathrm{Ra}_{\mathrm{eq}}$ is among well known and most widely used to estimate radiation hazard index or radiation hazard parameter or radiological index. In this estimation, the specific activities of radium, thorium, and potassium in different combinations in soil samples were compared, where $\mathrm{Ra}_{\mathrm{eq}}$ is defined as bellows (Beretka \& Mathew 1985):

$$
R a_{\mathrm{eq}}=A_{\mathrm{Ra}}+1.43 A_{\mathrm{Th}}+0.07 A_{\mathrm{K}}
$$

Where, $\mathrm{C}_{\mathrm{Ra}}, \mathrm{C}_{\mathrm{Th}}$ and $\mathrm{C}_{\mathrm{K}}$ are the specific activity concentrations for ${ }^{226} \mathrm{Ra}\left({ }^{238} \mathrm{U}\right)$, ${ }^{232} \mathrm{Th}$ and ${ }^{40} \mathrm{~K}$ (in $\mathrm{Bq} / \mathrm{kg}$ ), respectively. This equation is based on the estimate that 1 $\mathrm{Bq} / \mathrm{kg}$ of ${ }^{226} \mathrm{Ra}\left({ }^{238} \mathrm{U}\right), 259 \mathrm{~Bq} / \mathrm{kg}$ of ${ }^{232} \mathrm{Th}$ and $4810 \mathrm{~Bq} / \mathrm{kg}$ of ${ }^{40} \mathrm{~K}$ generate the same $\gamma$ - ray dosage rate (Stranden 1979; Yang et al. 2005; Ahmed 2005). For the nonhazardous, the calculated $\mathrm{Ra}_{\mathrm{eq}}$ should not exceed a maximum value of $370 \mathrm{~Bq} / \mathrm{kg}$ as reported by UNSCEAR (1982). (ii) External radiation hazard, $\mathrm{H}_{\mathrm{ex}}$ :

To estimate the additional radiological hazard on the people which are daily exposed to the natural gamma radiation from soil, the external radiation hazard, $\mathrm{H}_{\mathrm{ex}}$ was calculated using the following equation as reported earlier by Yang et al. (2005) and Nabil et al. (2010):

$H_{\mathrm{ex}}=\left(A_{\mathrm{U}} / 370\right)+\left(A_{\mathrm{Th}} / 259\right)+\left(A_{\mathrm{K}} / 4810\right) \leq 1$

Where, $A_{\mathrm{U}}, A_{\mathrm{Th}}$ and $A_{\mathrm{K}}$ are the activity concentrations for ${ }^{238} \mathrm{U}\left({ }^{226} \mathrm{Ra}\right),{ }^{232} \mathrm{Th}$ and ${ }^{40} \mathrm{~K}$ in $\mathrm{Bq} / \mathrm{kg}$, respectively. The values of the indices should be $\leq 1$ (Krieger 1981).

(iii) The total air absorbed dosage rate

The total air absorbed dosage rate, $D(\mathrm{nGy} / \mathrm{hr})$ due to the mean activity concentrations of ${ }^{238} \mathrm{U},{ }^{232} \mathrm{Th}$ and ${ }^{40} \mathrm{~K}$ in $\mathrm{Bq} / \mathrm{kg}$ is estimated using equation given by UNSCEAR (2000), Venkidasamy et al. (2011), UNSCEAR (2008) and, Sheela and Shanthi (2016);

$$
D=0.462 A_{\mathrm{U}}+0.604 A_{\mathrm{Th}}+0.0417 A_{\mathrm{K}}
$$

Where, $A_{U}, A_{T h}$ and $A_{K}$ are the activity concentrations for ${ }^{238} \mathrm{U}\left({ }^{226} \mathrm{Ra}\right),{ }^{232} \mathrm{Th}$ and ${ }^{40} \mathrm{~K}$ in $\mathrm{Bq} / \mathrm{kg}$, respectively. Sheela and Shanthi (2016) derived this equation for calculating the total air absorbed dosage rate in air at the height of $1.0 \mathrm{~m}$ above from the ground that measured the activity concentrations for uniform distribution of naturally occurring radionuclides in the environmental materials. 


\section{RESULTS AND DISCUSSION}

\section{Radioactivity Level of ${ }^{226} \mathrm{Ra},{ }^{228} \mathrm{Ra},{ }^{238} \mathrm{U},{ }^{232} \mathrm{Th}$ and ${ }^{40} \mathrm{~K}$ in Soil}

The results of the activity concentrations $(\mathrm{Bq} /$ $\mathrm{kg}$ ) of ${ }^{226} \mathrm{Ra},{ }^{228} \mathrm{Ra},{ }^{238} \mathrm{U},{ }^{232} \mathrm{Th}$ and ${ }^{40} \mathrm{~K}$ in soil samples at a different location in the study area are presented in Figure 2. The activity concentration of ${ }^{226} \mathrm{Ra}$ in soil samples ranges from $8.7 \mathrm{~Bq} / \mathrm{kg}$ to $95.4 \mathrm{~Bq} / \mathrm{kg}$. For ${ }^{228} \mathrm{Ra}$ found to be in the range of $6.6 \mathrm{~Bq} / \mathrm{kg}$ to $134.0 \mathrm{~Bq} / \mathrm{kg}$. The activity concentration of ${ }^{238} \mathrm{U}$ and ${ }^{232} \mathrm{Th}$ varied from $8.7 \mathrm{~Bq} / \mathrm{kg}$ to $106.0 \mathrm{~Bq} / \mathrm{kg}$ and $6.2 \mathrm{~Bq} / \mathrm{kg}$ to $130.0 \mathrm{~Bq} / \mathrm{kg}$, respectively. Meanwhile, the activity concentration of ${ }^{40} \mathrm{~K}$ in soil found to vary from $10.6 \mathrm{~Bq} / \mathrm{kg}$ to $1160.0 \mathrm{~Bq} / \mathrm{kg}$. These results showed a broad range of radioactivity level where some locations appeared to be higher. This noticeable difference may be attributed to the geochemical composition and origins of soil types in particular study areas (Dabayneh et al. 2008; Thabayneh \& Jazzar 2012). Moreover, the higher values of the activity concentrations belong to soil samples which may be attributed to soil types which were probably radioactiverich granite, phosphate, sandstone, and quartzite (UNSCEAR 1993; UNSCEAR 2002).

The average activity concentrations of ${ }^{226} \mathrm{Ra}$ measured in the present study were comparable to the value reported for offsite Lynas Plant sampling stations during the pre-operational as well as the value reported for worldwide and other countries such as China, Japan, India as summarized in Table 1. Thorium-232 $\left({ }^{232} \mathrm{Th}\right)$ found to be higher average values compared to Thailand, China, Japan and world values. The high variability of result attributed mainly to the typical concentration of the radioactive materials in soil, especially in Malaysian soil (Ismail 2009). Meanwhile, activity concentration of ${ }^{40} \mathrm{~K}$ in the soil at the present study found to be far lower than other countries. Observation revealed that the measured activity concentration of ${ }^{40} \mathrm{~K}$ significantly exceeded other natural radionuclides. This shows that ${ }^{40} \mathrm{~K}$ is a more abundance radionuclide compared to other radionuclides in the soils (Thabayneh \& Jazzar 2012). Furthermore, due to ${ }^{40} \mathrm{~K}$ is a highly mobile and easy to dissolve radionuclide, its variation might be due to spreading of widely used industrial materials (fertilizer, chemicals, etc.) at Gebeng industrial area (Yii et al. 2016). Another result showed the activity concentrations of ${ }^{232} \mathrm{Th}\left({ }^{228} \mathrm{Ra}\right)$ were higher than ${ }^{238} \mathrm{U}\left({ }^{226} \mathrm{Ra}\right)$ at all studied locations. This was mainly due to the decay property that may play an important role in rapid generating of ${ }^{228} \mathrm{Ra}$ (half-life: 5.75 years) from its parent of ${ }^{232} \mathrm{Th}$ compared to ${ }^{226} \mathrm{Ra}$ with long half-life of 1602 years which decay from ${ }^{232} \mathrm{U}$ (Moore et al. 1995; Krest et al. 1999).

\section{Radiological Index}

The radium equivalent activity concentration index, $\mathrm{Ra}_{\mathrm{eq}}$, the external radiation hazard, $\mathrm{H}_{\mathrm{ex}}$ and the total air absorbed dosage rate, $D$ are summarized in Figure 3. The radium equivalent activity concentration index, $\mathrm{Ra}_{\mathrm{eq}}$ and the external radiation hazard, $\mathrm{H}_{\mathrm{ex}}$ are radiological index, defined as the radiation hazard index which is used to assess the radiation hazard of the gamma ray due to the present of NORM radionuclides (Yii et al. 2016). Their estimations varied from $19.0-$ $335.9 \mathrm{~Bq} / \mathrm{kg}$ (mean: $139.6 \mathrm{~Bq} / \mathrm{kg}$ ) and 0.05 - 0.94 (mean: 0.39), respectively. The value of $\mathrm{Ra}_{\mathrm{eq}}$ found to be not exceeding a maximum value of $370 \mathrm{~Bq} / \mathrm{kg}$ as reported by UNSCEAR (1982). Meanwhile, the value of the $\mathrm{H}_{\mathrm{ex}}$ indices was less than unity (the values of the $\mathrm{H}_{\mathrm{ex}}$ should be $\leq 1)$ (Krieger 1981). Thus, these findings reflected negligible radiation hazard in the vicinity of Lynas plants negligible. In other words, there were no additional radiation level and no radiological hazard that may effect the people living in the surrounding areas. 

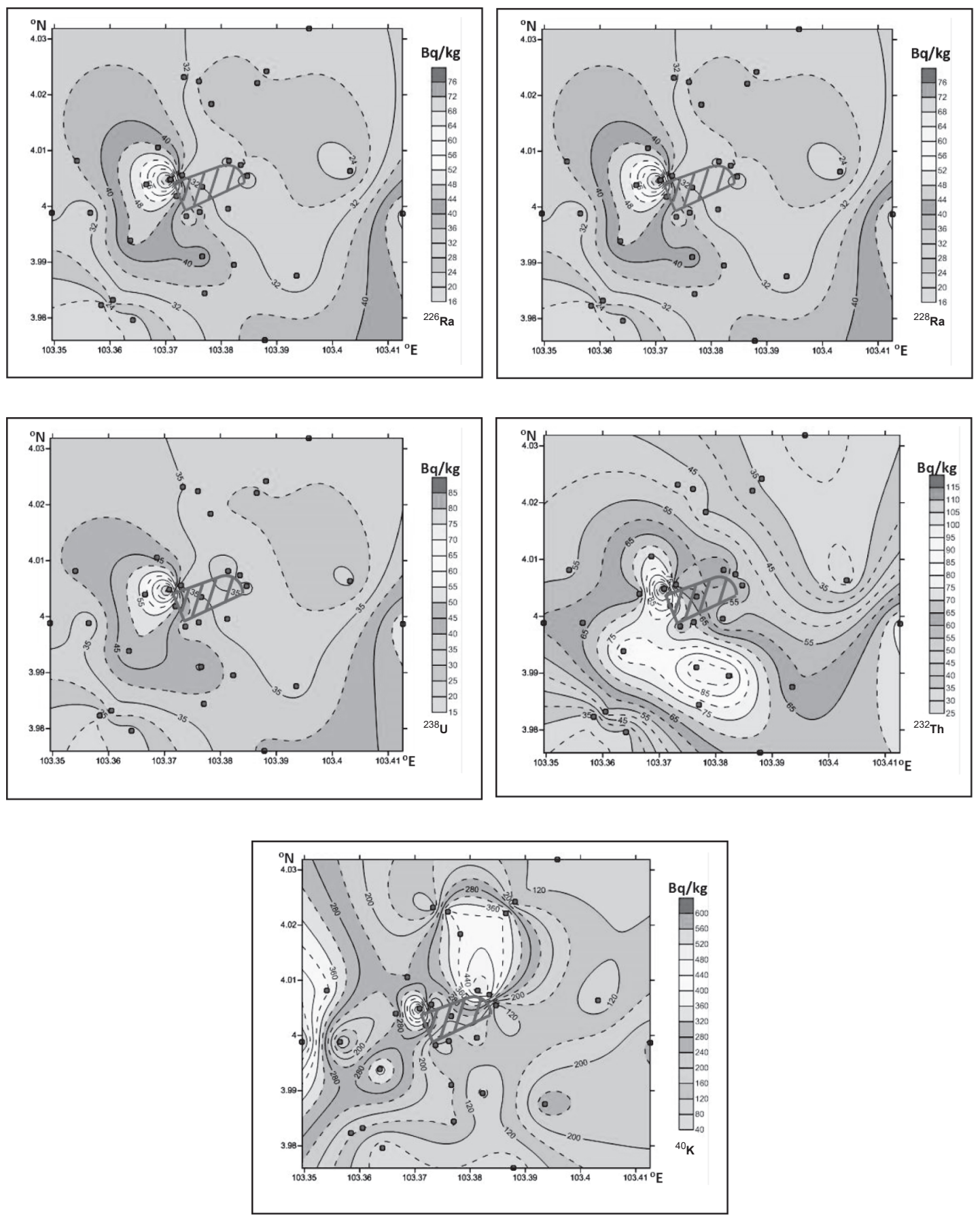

Figure 2. Soil radioactivity level of ${ }^{226} \mathrm{Ra},{ }^{228} \mathrm{Ra},{ }^{238} \mathrm{U},{ }^{232} \mathrm{Th}$ and ${ }^{40} \mathrm{~K}$ in the vicinity of Lynas plant. 
W.M. Zal U'yun et al.: Radioactivity Level and Radiological Index-Lynas Rare-earth Processing Plants

Table 1. Comparison of radioactivity concentrations for ${ }^{226} \mathrm{Ra},{ }^{228} \mathrm{Ra},{ }^{238} \mathrm{U},{ }^{232} \mathrm{Th}$ and ${ }^{40} \mathrm{~K}$ in soil.

\begin{tabular}{|c|c|c|c|c|c|c|}
\hline \multirow{2}{*}{ Location } & \multirow{2}{*}{ Level } & \multicolumn{5}{|c|}{ Activity concentration of radionuclide $(\mathrm{Bq} / \mathrm{kg})$} \\
\hline & & ${ }^{226} \mathrm{Ra}$ & ${ }^{228} \mathrm{Ra}$ & ${ }^{238} \mathrm{U}$ & ${ }^{232} \mathrm{Th}$ & ${ }^{40} \mathrm{~K}$ \\
\hline \multirow{3}{*}{ This study } & Minimum & 9 & 7 & 9 & 6 & 11 \\
\hline & Maximum & 95 & 134 & 106 & 130 & 1160 \\
\hline & Average & 35 & 62 & 38 & 60 & 245 \\
\hline \multirow{3}{*}{$\begin{array}{l}\text { Onsite Lynas plant (pre-operational) } \\
\text { (Ismail 2009) }\end{array}$} & Minimum & 13 & 25 & - & - & - \\
\hline & Maximum & 56 & 178 & - & - & - \\
\hline & Average & 26 & 64 & - & - & - \\
\hline \multirow{3}{*}{$\begin{array}{l}\text { Offsite Lynas plant (pre-operational) } \\
\text { (Ismail 2009) }\end{array}$} & Minimum & 12 & 10 & - & - & - \\
\hline & Maximum & 57 & 83 & - & - & - \\
\hline & Average & 32 & 69 & - & - & - \\
\hline Pahang (Ismail 2009) & Average & 71 & 88 & - & - & - \\
\hline \multirow[t]{2}{*}{ Peninsular Malaysia (Ismail 2009) } & Average & 74 & 98 & - & - & - \\
\hline & Minimum & 38 & - & 49 & 63 & 170 \\
\hline \multirow[t]{3}{*}{ Malaysia (UNSCEAR 2000) } & Maximum & 94 & - & 86 & 110 & 430 \\
\hline & Average & 67 & - & 66 & 82 & 310 \\
\hline & Minimum & 41 & - & - & 105 & 75 \\
\hline \multirow[t]{3}{*}{ Malaysia (Mohsen et al. 2007) } & Maximum & 90 & - & - & 516 & 848 \\
\hline & Average & - & - & - & - & - \\
\hline & Minimum & 20 & - & - & 25 & 36 \\
\hline \multirow[t]{2}{*}{ Phuket Island (Chanyotha 2011) } & Maximum & 390 & - & - & 530 & 2610 \\
\hline & Average & 94 & - & - & 190 & 720 \\
\hline
\end{tabular}


Table 1 Cont. Comparison of radioactivity concentrations for ${ }^{226} \mathrm{Ra},{ }^{228} \mathrm{Ra},{ }^{238} \mathrm{U},{ }^{232} \mathrm{Th}$ and ${ }^{40} \mathrm{~K}$ in soil.

\begin{tabular}{|c|c|c|c|c|c|c|}
\hline \multirow[b]{2}{*}{ Location } & \multirow[b]{2}{*}{ Level } & \multicolumn{5}{|c|}{ Activity concentration of radionuclide $(\mathrm{Bq} / \mathrm{kg})$} \\
\hline & & ${ }^{226} \mathrm{Ra}$ & ${ }^{228} \mathrm{Ra}$ & ${ }^{238} \mathrm{U}$ & ${ }^{232} \mathrm{Th}$ & ${ }^{40} \mathrm{~K}$ \\
\hline \multirow{3}{*}{ Thailand (UNSCEAR 2000) } & Minimum & 11 & - & - & 7 & 7 \\
\hline & Maximum & 78 & - & - & 120 & 712 \\
\hline & Average & 48 & - & - & 51 & 230 \\
\hline \multirow{3}{*}{ China (UNSCEAR 2000) } & Minimum & 2 & - & - & 1 & 9 \\
\hline & Maximum & 440 & - & - & 360 & 1800 \\
\hline & Average & 32 & - & - & 41 & 440 \\
\hline \multirow{3}{*}{ Hong Kong (UNSCEAR 2000) } & Minimum & 20 & - & - & 16 & 81 \\
\hline & Maximum & 110 & - & - & 200 & 1100 \\
\hline & Average & 59 & - & - & 95 & 530 \\
\hline \multirow{3}{*}{ Japan (UNSCEAR 2000) } & Minimum & 6 & - & - & 2 & 15 \\
\hline & Maximum & 98 & - & - & 88 & 990 \\
\hline & Average & 33 & - & - & 28 & 310 \\
\hline \multirow{3}{*}{ India (UNSCEAR 2000) } & Minimum & 7 & - & - & 14 & 38 \\
\hline & Maximum & 81 & - & - & 160 & 760 \\
\hline & Average & 29 & - & - & 64 & 400 \\
\hline Worldwide (UNSCEAR 2000) & Average & 35 & - & - & 30 & 400 \\
\hline World average (Yii et al. 2016) & Average & - & - & 45 & 33 & 420 \\
\hline
\end{tabular}



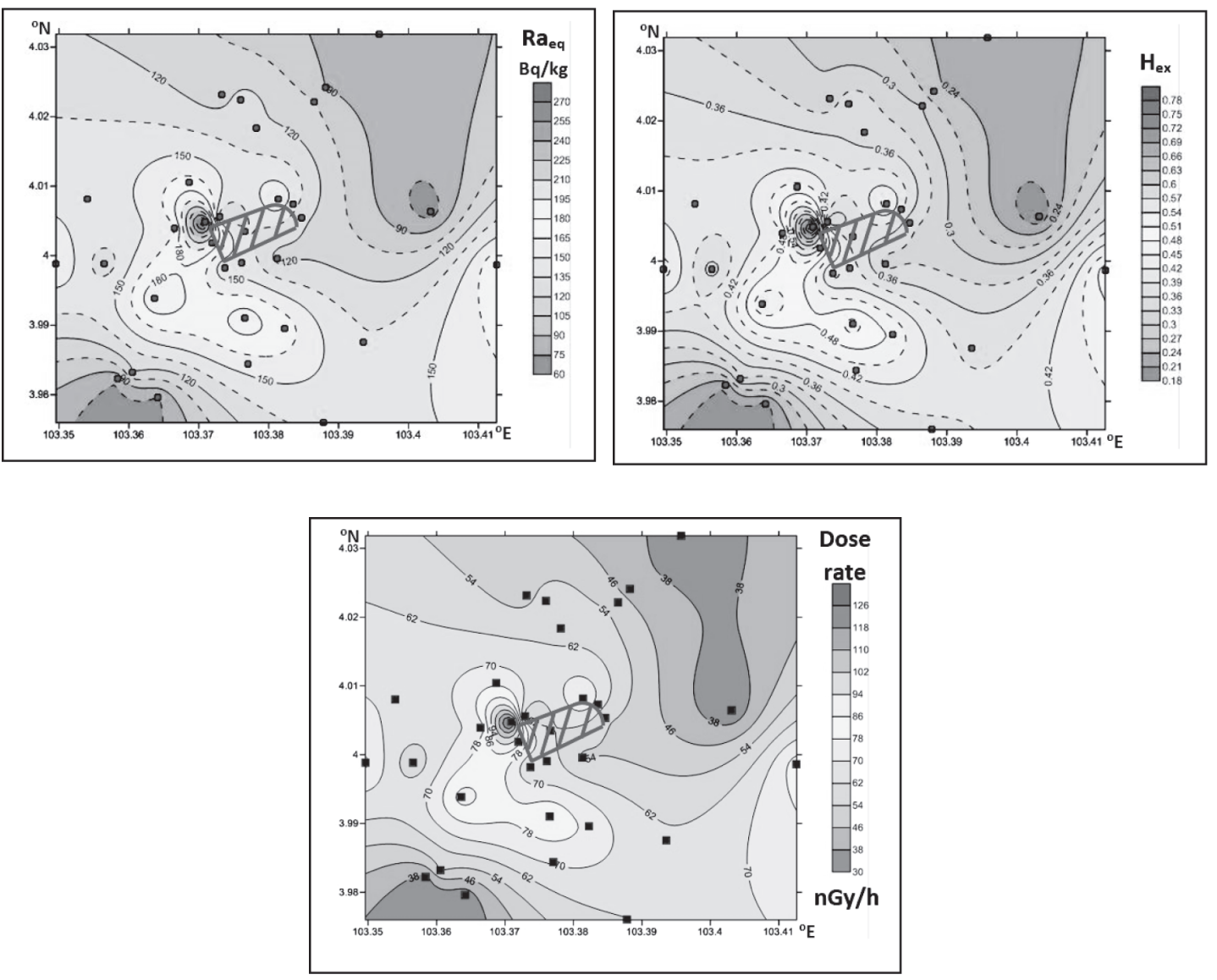

Figure 3. Profile of radiological index in the vicinity of Lynas plant.

The total air dosage rate for the outdoor environment calculated from the absorbed dosage rate in the study area was found to be varying from $8.6-157.1 \mathrm{nGy} / \mathrm{h}$ with a mean value of $64.2 \mathrm{nGy} / \mathrm{h}$. This was slightly higher than the estimated average global terrestrial radiation of $55 \mathrm{nGy} / \mathrm{h}$ (range: $28-120 \mathrm{nGy} / \mathrm{h}$ ), $57 \mathrm{nGy} / \mathrm{h}$ (range: 18 - $93 \mathrm{nGy} / \mathrm{h}$ ) and $62 \mathrm{nGy} / \mathrm{h}$ reported by UNSCEAR (1993), UNSCEAR (2000),] and Hien et al. (2002), respectively. However, this value is much lower compared to the value recorded in Ulu Tiram with a range of 96 - $409 \mathrm{nGy} / \mathrm{h}$ (mean: $200 \mathrm{nGy} / \mathrm{h}$ ) (AbdulRahman 2007), 55 - 130 nGy/h (mean: 92
$\mathrm{nGy} / \mathrm{h}$ ) for Peninsular Malaysia (UNSCEAR 2000), and $2-100 \mathrm{nGy} / \mathrm{h}$ (mean: $77 \mathrm{nGy} / \mathrm{h}$ ) for Thailand (UNSCEAR 2000). The radiological index or radiation hazard parameters at some locations in the study area slightly exceeded the UNSCEAR average range but lower than Peninsular Malaysia might be due to natural occurrence of a relatively high activity concentration of natural radionuclides in the soil at particular locations. Usually, they were attributed to soil types which probably contained natural radioactive-rich minerals such as granite, monazite, quartzite, etc. 


\section{CONCLUSIONS}

The activity concentration level of ${ }^{226} \mathrm{Ra},{ }^{228} \mathrm{Ra}$, ${ }^{238} \mathrm{U},{ }^{232} \mathrm{Th}$ and ${ }^{40} \mathrm{~K}$ measured in the 31 soil samples collected from the vicinity of Lynas rare-earth processing plant were the broad range where some small locations appeared to be higher. These relatively higher values and noticeable difference in some locations might be attributed to the geochemical composition and origins of soil types in particular study areas. Thus, the impacts of these natural radionuclides and the corresponding additional external radiation if any, exposure to the public were almost negligible. Consequently, the measured levels of these natural radionuclides confirmed that there were no hazard effects on the people residing in the vicinity of the Lynas Plant. Apart from that, the finding of this study could contribute to the setting up of a reference level for studies about natural radioactivity in the soil samples of this region in future.

\section{AKNOWLEDGEMENT}

The authors would like to express their special appreciation to the Ministry of Science, Technology and Innovation for providing research funding under the ScienceFund research grant (06-03-01-SF0189). Special thanks is also commited to the Pahang State Development Corporation for assisting in the execution of this project at Gebeng Industrial Estate. The authors are also thankful to the staff for their kind co-operation and support in implementation this project.

Date of receipt: April 2017 Date of acceptance: July 2017

\section{REFERENCES}

Abdul-Rahman, AT \& Ramli, AT 2007, 'Radioactivity levels of ${ }^{238} \mathrm{U}$ and ${ }^{232} \mathrm{Th}$, the $\alpha$ and $\beta$ activities and associated dose rates from surface soil in Ulu Tiram, Malaysia', J. Radioanal. Nucl. Chem., vol. 273, pp. 653-657.

Ahmad-Taufek, AR, Ahmad-Termizi, R \& Abdul-Khalik, W 2004, 'Analysis of the concentration of natural radionuclides in rivers in Kota Tinggi District, Malaysia', $J$. Nucl. Related Technol., vol. 1, pp. 41-52.

Ahmed, NK \& El-Arabi, AGM 2005, 'Natural radioactivity in farm soil and phosphate ferterlizer and its environmental implications in Qena governorate, Upper Egypt', $J$. Environ. Radioact., vol. 84, pp. 51-64.

Akram, M, Qureshi, RM, Ahmad, N, Solaija, TJ, Mashiatullah, A, Ayub, MA \& Irshad, S 2004, 'Determination of natural and artificial radionuclides in seawater and sediments off Gwadar Coast, Arabian Sea', The Nucleus, vol. 41, pp. 19-25.

Balakrishnan, D, Umadevi, AG, Abraham, JP, JoJo, PJ, Harikumar, M \& Radhakrishnan, S 2015, 'Assessment of natural radioactivity level and radiation hazard parameters in the terrestrial environment of Eloor Island, Kerala', Int. J. Fundam. Physic. Sci., vol. 5, no. 2, pp. 38-42.

Beretka, J \& Mathew, P 1985, 'Natural radioactivity of Australian building materials, industrial wastes and by-products', Health Phys., vol. 48, no. 1, pp. 87-95.

Chanyotha, S, Kranrod, C, Tokonami, S, Suwankot, N, Pangza, K \& Pornnumpa, C 2011, 'Terrestrial gamma radiation in Phuket Island, Thailand', Engin. J., vol. 15, no. 4. 
Dabayneh, K, Masha, 1 L \& Hasan, F 2008, 'Radioactivity concentration in soil samples in the southern part of the West Bank, Palestine', Radiat. Prot. Dos., vol. 131, pp. 265-271.

Dowdall, M \& O’Dea, J 2002, ${ }^{226} \mathrm{Ra} /{ }^{238} \mathrm{U}$ disequilibrium in an upland organic soil exhibiting elevated natural radioactivity', J. Environ. Radioact., vol. 59, pp. 91-104.

El-Reefy, HI, Sharshar, T, Zaghloul, R \& Badran, HM 2006, 'Distribution of gamma-ray emitting radionuclides in the environment of Burullus Lake: I. soils and vegetation', J. Environ. Radioact., vol. 87, pp. 148-169.

Hien, PD, Hiep, HT, Quang, NH, Luyen, TV, Binh, NT, Long, NQ \& Bac, VT 2002, 'Environmental radionuclides in surface soils of Vietnam', Sci. World J., vol. 26, pp. 1127-1131.

$\mathrm{Hu}, \mathrm{QH}$, Weng, JQ \& Wang, JS 2010, 'Sources of anthropogenic radionuclides in the environment: a review, J. Environ. Radioactiv, vol. 101, pp. 426-437.

IAEA 2005, Long-term stabilization of Uranium Mill Tailings, 1st edn, International Atomic Energy Agency, Vienna.

IAEA 2010, Radioelement mapping nuclear energy series no. NF-T-1.3, Vienna.

Ismail, S, Khairuddin, MK \& Muhamat, O 2009, Pre-operational radiological and environmental monitoring at proposed Lynas Plant site, Gebeng, Pahang, Laporan Teknikal UPP/2009/LM/PREOP (13).

Kasoga, KF, Mwalongo, DA, Sawe, SF, Nyaruba, MM \& Dammalapati, U 2015, 'Ambient gamma dose rate measurements at Manyoni uranium deposits, Singida, Tanzania', in Proceedings of SA Institute of Physics, pp. 180-185.
Krest, J.M., Moore, W.S. and Rama. (1999), Ra-226 and Ra-228 in the mixing zones of the Mississippi and Atchafalaya Rivers: Indicators of groundwater input, Mar. Chem., vol. 64, pp. 129-152.

Krieger, R 1981, 'Radioactivity of construction materials', Betonwerk Fertigteil Techn., vol. 47, p. 468.

Mohsen, N, Bahari, I, Abdullah, P \& Jaafar, A 2007, 'Gamma hazards and risk associated with NORM in sediment from among processing recycling ponds', Malaysian J. Anal. Sci., vol. 11, no. 1, pp. 314-323.

Moore, WS, Astwood, H \& Lindstrom, C 1995, 'Radium isotopes in coastal water on the Amazon Shelf', Geochimica Cosmochimica Acta, vol. 59, pp. 4285-4298.

Nabil, MH, Tetsuo, I, Masahiro, H, Atsuyuki, S, Shinji, T, Masahiro, F \& Sarata, KS 2010, 'Assessment of the natural radioactivity using two techniques for the measurement of radionuclide concentration in building materials used in Japan', J. Radioanal. Nucl. Chem., vol. 283, pp. 15-21.

Sheela, MUR \& Shanthi, G 2016, 'Evaluation of radiation hazard indices due to the rock samples of western Ghats of South Tamilnadu', Int. J. Adv. Res., vol. 4, no. 12, pp. 486-495.

Stranden, E 1979, 'A simple method for measuring the radon diffusion coefficient and exhalation rate from building materials', Health Phys., vol. 37, pp. 242-244.

Thabayneh, K \& Jazzar, M 2012, Natural radioactivity levels and estimation of radiation exposure in environmental soil samples from Tulkarem Province Palestine, Open J. Soil Sci., vol. 2, pp. 7-16. 
UNSCEAR 1982, Ionizing radiation: sources and biological effects, United Nations, New York.

UNSCEAR 1993, Report to the General Assembly, New York, NY, USA.

UNSCEAR 2000, Sources, effects and risks of ionizing radiation, Report to the General Assembly, with scientific annexes, United Nations, New York.

UNSCEAR 2008, Sources and effects of ionizing radiation. Exposures of the public and workers from various sources of radiation, Report to the General Assembly with Scientific Annex-B. United Nations, New York.

Venkidasamy, R, Pachamuthu, R, Govindasamy, $\mathrm{S}$, Venkatasubramanian, $\mathrm{M} \&$ Velladurai, $\mathrm{P}$
2011, 'Determination of level of radioactivity and evaluation of radiation hazardous nature of the recently excavated river sediments', Carpath. J. Earth Env., vol. 6(1), pp. 141-146.

Yang, YX, Wu, XM, Jiang, ZY, Wang, WX, Lu, JG, Lin, J, Wang, LM \& Hsia, YF 2005, 'Radioactivity concentrations in soils of the Xiazhuang granite area, China', Appl. Radiat. Isot., vol. 63, pp. 255-259.

Yii, et al. 2016, Ambient radioactivity and radiological studies in the vicinity of Lynas Rare-Earth Processing Plant, Gebeng Industrial Estate, Kuantan, Pahang, Technical Report ScienceFund Project, NUCLEARMALAYSIA/L/2016/96. 